\title{
Gharacteristics and developments in the production of sheep and goat meat in Australia
}

\author{
B. J. RESTALL
}

N. S. W. Department of Agriculture, P. O. Box 239, Blacktown 2148 N. S. W. (Australia).

The Australian lamb industry produces 16 million lambs annually, 88 per cent of which are sold on the domestic market. These lambs come from a tired breeding structure in which cross-bred ewes (usually Border Leicester $\times$ Merino), derived from Merino wool-growing flocks, are joined to short wool rams such as the Dorset Horn or Southdown. Other breeds used to a lesser extent include Dorset Horn $\times$ Merino, Corriedale and Polworth ewes, and Border Leicester, Ryeland, Suffolk and Romney Marsh sires. Many trials have shown the superiority of the Border Leicester $x$ Merino and Dorset Horn $\times$ Merino ewes joined to Dorset Horn sires for the production of prime lamb. Lambing percentages vary between go- $70 \%$ and lambs from these crosses grow at rates of $0.24-0.30 \mathrm{~kg} /$ day.

With the decline in Australian traditional export markets, interest has turned to the Middle Eastern Muslim market, which requires a heavier $(22-28 \mathrm{~kg})$, leaner carcass. Suffolk sires are being used to produce the required type of lamb ( $48 \mathrm{~kg}$ liveweight) at 9 months of age. Young Merino sheep up to $3 \mathrm{I} / 2 \mathrm{yrs}$ of age are currently supplied to the Muslim market as chilled carcasses. To increase the profitable production of this type of carcass in Merino wool growing flocks, farmers are increasing the proportion of ewes from $4^{\circ}$ to 60 per cent without increasing flock size.

The large flocks of feral goats in Australia have been intermittently harvested to provide small quantities of meat for export (for example 6 ooo kg exported to France 1974/75). About 50 ooo goats are slaughtered each year and yield carcasses between $10-22 \mathrm{~kg}$ according to age.

Studies of these goats have shown that they are prolific (kidding percentage above $\mathbf{1}_{50} \mathrm{O}$ per cent) and the kids grow at about $1.0 \mathrm{~kg} /$ week until weaning. As these goats preferentially browse there is a large potential use for them in rangeland management and studies have begun to improve their meat production by selection and breeding.

\section{Growth and quality of prime Kid carcasses}

\author{
P. M. FEHR (*), D. SAUVANT $\left({ }^{*}\right)$ and B. L. DUMONT $\left({ }^{* *}\right)$ \\ (*) Laboratoire de Recherches de la Chaive de Zootechnie, I.N.R.A., \\ Institut National agronomique Paris-Grignon, \\ I6, me Claude Bernard, 7523 I Paris Cedex o5. \\ (**) Laboratoire de Recherches sur la Viande, \\ C.N.R.Z., I.N.R.A., Domaine de Vilvert, 78350 Jouy-en-Josas.
}

This report analyses the growth characteristics and quality of kid carcass and meat. The daily mean gain ( $\mathrm{g} /$ day) of male Alpine kids receiving only milk replacer can easily reach values of 250 during the first month. The daily mean gain tends to decrease when the liveweight exceeds $16 \mathrm{~kg}$ at slaughter. The commercial dressing percentage (carcass + head + liver + heart + lungs + spleen) of light-weight kid is about $66-67 \%$. Generally, the net dressing percentage (carcass /empty liveweight) of heavy-weight kid ( $16-32 \mathrm{~kg}$ L.W.) reaches about $52-54 \%$. 